\title{
Adaptation of Children to Preschool Institutions in the Changed Conditions of COVID 19
}

\author{
Jurka Lepičnik Vodopivec \\ Univerza na Primorskem \\ jurka.lepicnik@pef.upr.si \\ Aleksandra Šindić \\ University of Banja Luka \\ aleksandra.sindic-radic@ff.unibl.org
}

\begin{abstract}
The COVID 19 pandemic has also affected change in education, including changes perceived in the context of the transition of children from a family to a kindergarten environment. The aim of our qualitative research is to study the experiences of all stakeholders in education in kindergartens (children, preschool teachers and parents) in the Republic of Slovenia and the Republic of Bosnia and Herzegovina during the pandemic. For this purpose, we designed an instrument with six open-ended questions, which surveyed 20 preschool teachers (10 from each country). The data obtained in March 2021 shed light on the specifics of children's adaptation to kindergarten during the COVID 19 pandemic and the experiences of children, preschool teachers and parents from the perspective of the surveyed preschool teachers. Based on the obtained data, we conclude that the adjustment was, in the opinion of the respondents, successful and in some cases more successful than usual.
\end{abstract}

Keywords: adaptation of children to kindergarten, professional preschool teachers' experiences, cooperation between parents and preschool teachers

\section{Introduction}

Transitions as a connection between different environments and levels of education could be said to be most pronounced in early childhood, because for most children they represent the first separation from parents and the first experience with an institutional upbringing and education (Velan and Vorkapić 2020). At an early age, they are strongly focused on adaptation in terms of emotional and social categories, and children's development and educational work depend on its success (Kamenov 2006), and from the point of view of attachment theory, achieving a secure connection between children and preschool teachers is of importance for the quality of educational work in kindergarten (Cugmas 2010). Kroflič (2001) notes that the autonomy 
of preschool teachers significantly contributes to the quality of educational work in kindergarten and encourages the autonomy of children. This is confirmed by the insights of Eurydice (Plevnik 2008) and the research of Zupančič (2013) and Iftene (2014). We understand the autonomy of preschool teachers as freedom in choosing and shaping the content, tasks and methods of work, didactic tools and materials, and taking responsibility for evaluating their own work.

The adaptation of children to kindergarten is a process in which parents and preschool teachers and coordination and cooperation between them have an important role (Lepičnik Vodopivec 2012); if we want to understand this complex process, we must take into account all participants involved (children, preschool teachers and parents). The study of the context (environment) in which the child is involved, viewed through Bronfenbrenner's (1981) theory of ecological systems, once again indicates its importance and interdependence between children's learning and development within the environment in which the child is located, and that for a small child, those environments with which the family is in direct contact (microsystems), and later the preschool institution, and their connection and cooperation (mesosystem) are of crucial importance.

At the time of the COVID 19 pandemic, inadequate changes in these systems were observed, as indicated by numerous modern tests. In a research on a sample of 169 preschool teachers in Serbia, Stoiljković (2020) obtained information on their flexibility and adaptability to the new situation and work, but also the view that non-attendance at preschool will have the most adverse effect on the social, emotional and finally intellectual and physical development of children, while in their study, Dong, Cao, and Li (2020) point to bad experiences with preschool children who stayed home during the pandemic and had online education, and Gayatri (2020) promotes the importance of parent-preschool teacher collaboration for the success of this type of education. O'Keeffe and McNally (2021), based on the insights of 320 teachers of young children ( 4 to 7 years) in the Republic of Ireland, conclude that children need support in the socio-emotional sphere when returning to school, and point to play as an important pedagogical tool in the development of resilience. Spinelli et al. (2020), in a study conducted in Italy with parents of children aged 2 to 14 , identified the frequency of parental stress and their children's psychological and behavioural problems while staying in quarantine.

Research conducted in Serbia has indicated changes in the functioning of the family and the division of responsibilities and care for children in such 
conditions (Čikić and Bilinović Rajačić 2020), while Jokić Begić et al. (2020), in a study with 400 parents of preschool and school children in Croatia, notes that every third parent stated that parenting was more difficult during the pandemic than before, and that every fourth parent had more conflicts with children during the pandemic, but did not express a high degree of concern about the possible adverse effects of pandemic measures on their children's development. Given the unfavourable changes in microsystems and mesosystems important for children's development and learning during COVID 19, and the importance of a successful transition from family home to kindergarten, we wanted to explore preschool teachers' experiences of adapting children to kindergartens after their reopening during the COVID 19 pandemic with changed working conditions and regimes (in accordance with regulations). Due to the topicality of the researched situation, we did not find any works dealing with the adaptation of children to kindergarten during the COVID 19 pandemic after their resumption of work.

\section{Method}

When kindergartens reopened during the COVID 19 pandemic, not only children who came to kindergarten for the first time but also other children (who had not been to kindergarten for a long time) needed some kind of adaptation to the kindergarten.

We wanted to understand and look at the adaptation of all children to kindergarten after their reopening in the changed conditions of COVID 19 for all participants involved in this process (children, preschool teachers and parents) from the point of view of preschool teachers, which was the research goal. In our study of a qualitative, exploratory type, we used an independently constructed research instrument - a survey with six questions of open type (essay type). Through it, we tried to collect data on the adaptation of children to kindergarten and the experiences of participants in educational work (children, preschool teachers and parents) through the perception of the surveyed preschool teachers. In crisis situations, such as a pandemic, the support of adults is important to the child, their emotional stability and readiness to meet children's needs, provide security and help in emotional processing of difficult mental situations (Kruger and Reddemann 2013; Profaca and Arambašić 2009), and in addition to practical experiences of adaptation, we are equally interested in the emotional response and stability of adults involved in the adaptation process. Two questions were related to the emotions and experiences of preschool teachers, two questions were related to the emotions and experiences of parents, and two questions were related to 
the emotions and experiences of children in the process of adapting children to kindergarten. Pre-research conducted as an oral survey with four participants showed that the instrument used has the potential to develop a theory, which is one of the strategies for verifying the validity and reliability of a research instrument by allowing thinking between micro perspective data and macro conceptual/theoretical understanding (Morse et al. 2002). Based on a written survey conducted in March 2021, we noticed that the data collected under the same conditions from all participants represent authentic experiences in the given context, as well as content for inductive construction of local theory, which is one of the indicators of instrument validity (Merriam and Tisdell 2015).

20 preschool teachers participated in the research: 10 from the Republic of Slovenia from kindergartens from the coastal-karst and coastal-inland areas and 10 from Bosnia and Herzegovina, Republic of Srpska, from kindergartens in Banja Luka. Respondents were: six preschool teachers from the first age groups (children aged one to three years) and four preschool teachers from the second age groups (children aged three to six years) in Bosnia and Herzegovina, and four preschool teachers from the first age groups (children aged one to three years) and six preschool teachers from the second age groups (children aged three to six years) from kindergartens in Slovenia. The selection of respondents enabled us to conduct a comparative case study in the Republic of Slovenia and Bosnia and Herzegovina, i.e. we look at the experiences of participants in educational work (children, preschool teachers and parents) during the adaptation of children to kindergarten during COVID 19 (case study) through the insights of preschool teachers and compare insights, taking into account the broader context or macrosystem (Bronfenbrenner 1981) (the country). Thematic content analysis was used to analyse the respondents' responses (Kuckartz 2014; Vilig 2016). After the initial coding of the original statements of the respondents, the determination of topics followed. The two authors alternately checked the consistency of the coding and the overall analysis process.

The selection of respondents enabled us to conduct a comparative case study in the Republic of Slovenia and Bosnia and Herzegovina, i.e. we look at the experiences of participants in educational work (children, preschool teachers and parents) during the adaptation of children to kindergarten during COVID 19 (case study) through the insights of preschool teachers and compare insights taking into account the broader context or macrosystem (Bronfenbrenner 1981) i.e. the country. We wanted to see and understand the insights and observations of preschool teachers about possible changes dur- 
ing the adaptation of children to kindergarten during COVID 19, and the research questions were related to the educational perspective on:

- What are the changes in the emotional experience of preschool teachers and their professional success during the adaptation of children to kindergarten at the time of COVID 19 compared to the time before the pandemic?

- What are the changes in the emotional experience of parents and in the cooperation of preschool teachers and parents during the adaptation of children to kindergarten during COVID 19 in relation to the time before the pandemic?

- What are the changes in the emotional experience of children and the success of adaptation to kindergarten during COVID 19 compared to the time before the pandemic?

- Are there any differences during the adaptation of children to kindergarten during COVID 19 from the perspective of preschool teachers in different countries and what are they?

\section{Results and Discussion}

Before the realization of the pre-research and research, we looked at the social context in both countries with regard to the research case (adaptation of children to kindergarten during the time of COVID 19). There are some differences in the dates and length of the kindergarten closing period, but after their opening the newly introduced protection measures were almost identical.

Kindergartens in both countries were closed on March 16, 2020. In the Republic of Srpska (Bosnia and Herzegovina), kindergartens were closed until May 16, and then only some facilities with a limited number of children were gradually opened. In the Republic of Slovenia, kindergartens started operating on 18 May; they closed again on October 15, 2020. From October 2020 to February 15,2021 , kindergartens were closed, followed by the opening of kindergartens with a recommendation to reduce the number of children in the group (for children from 1 to 3 years up to 8 children, and for children from 3 to 6 years up to 10 children), which should be in separate rooms.

In accordance with further recommendations on mitigating measures to combat the pandemic of the Institute of Public Health of the Republic of Srpska, on June 1, 2020, all facilities started operating with the recommendation that a maximum of ten children stay in the group (ten days after the opening of all kindergartens in Slovenia). The number of children in educational 
groups gradually increased, in accordance with the improvement of the epidemiological situation and the recommendations of the Institute of Public Health of the Republic of Srpska, and from October 5, 2020, it reached the standards prescribed by the Law on Preschool Education of Republic of Srpska (Zakon o predškolskom vaspitanju i obrazovanju Republike Srpske 2020)

In March 2021, when the survey was conducted in both countries, kindergartens operated in the normal mode of operation in accordance with the recommendations of the World Health Organization and national institutes of public health (National Institute of Public Health (Nacionalni inštitut za javno zdravje 2020) and the Institute of Public Health of the Republic of Srpska). The recommendations refer to the establishment of a higher level of hygiene of the premises, employees and children. In accordance with the recommendations, numerous activities with children take place outside the kindergarten. Parents were forbidden to enter the kindergarten and were to hand over their children at the entrance gardens. In cases of emergency, they were allowed to enter kindergartens in the Republic of Slovenia (not in the Republic of Srpska).

In the Republic of Slovenia, during the research period, kindergartens worked with a smaller number of children than usual, and in the Republic of Srpska, in that period, kindergartens worked with a normal number of children.

Taking into account the above data that reflected on the specifics of work in kindergartens, we approached the analysis of educational responses, trying to answer research questions. We looked at the answers of preschool teachers in the context of participants key to the adaptation of children, and the following four categories were identified.

\section{Professional Experiences and Emotional Experiences of Preschool Teachers during the Adaptation of Children to Kindergarten in the COVID 19 Pandemic}

Admission of children to kindergartens after the reopening of institutions was gradual, and children who had not yet attended kindergarten were not admitted during the first few months. All this enabled the educators to adapt to the new situation of educational work, which they stated was confusing, tense and that it represented a professional challenge for them. The emotional response of preschool teachers was more pronounced than usual in terms of unpleasant emotions, but also pleasant emotions, but in addition, the statements show good emotional regulation which is an important prerequisite for providing support to the youngest in crisis situations (Kruger 
and Reddemann 2013; Profaca and Arambašić 2009) during the adaptation. Fear of uncertainty, emphasized caution and control in order to establish physical distance between children of the same group and the ban on contact between children from different educational groups in the open, frustration because some parents did not adhere to the prescribed measures, anxiety and sadness due to the new regime with reduced opportunities for social contact and more difficult working conditions are listed. Also, there is happiness and satisfaction due to returning to work, breaking isolation, meeting with colleagues and children, that things are getting better, and all that has caused relief and hope that the situation will soon return to normal.

There was fear and happiness that I was returning to work. [Segment of preschool teachers' answers, No 1, Slovenia]

In the early days, I was confused and frustrated because our job is specific. Protection measures required physical distance, and that is not possible in kindergarten. [Segment of preschool teachers' answers, No $5, \mathrm{BiH}]$

I felt relief, happiness and satisfaction for returning to work and meeting colleagues and children [...] [Segment of preschool teachers' answers, No 4, BiH]

Upon my return on May 18, 2020, I was upset, I was somehow afraid of what would happen to the children, whether they would need readaptation [...] these feelings were only partially present at the beginning, but everything subsided after a few minutes [...] [Segment of preschool teachers' answers, No 8, Slovenia]

Despite the fact that the experience of adapting children to kindergarten is stressful for preschool teachers themselves (Lepičnik Vodopivec 2012) in everyday conditions, preschool teachers approached it professionally during COVID 19. Preschool teachers' answers indicate their emphasized flexibility and adaptability to the new work regime, good team organization, cooperation and willingness to help colleagues within the institution. All these are important factors that enabled the work to be established in a satisfactory manner, and thus to obtain favourable conditions for the admission of new children to kindergarten. Modern research indicates that collegiality is an indispensable factor in adapting to new situations and circumstances of today, and its positive effect on professional development, learning and work organization (Shah 2012), and open communication in a team creates favourable 
working conditions that optimally contribute to children's development and learning (Flottman, McKernan, and Tayler 2011).

I think that I was more efficient in accepting children and adapting because I was preparing [...] and the professional service gave us support. [Segment of preschool teachers' answers, No 4, BiH]

I had a great team, which worked during the shift, we connected well with each other and with the children, so I look at it positively. I must also mention our director who is always on our side, who supported, motivated and supported us so that the work flowed smoothly and positively. [Segment of preschool teachers' answers, No 2, Slovenia]

Upon returning to the home kindergarten [...] we asked the housekeeper to be with the children while we go out and receive the child [...] [Segment of preschool teachers' answers, $\mathrm{No}_{3}, \mathrm{BiH}$ ]

Due to the new situation, preschool teachers say that they are more prepared to work with children than usual, in the first days they talk more about the situation, and activities take place mostly outside kindergarten (in accordance with the recommendations on pandemic control) and the emphasis is on social games (to empower children). Respondents from Slovenia and Bosnia and Herzegovina believe that they were effective during the adaptation of children, some even more efficient, showing a high degree of readiness for new challenges, and good preparation and adaptability, and similar data also came from research on a sample of 169 preschool teachers in Serbia (Stoiljković 2020). Also, respondents recognize play (social, outdoor, etc.) and conversation as a good strategy for developing children's resilience during adaptation in the age of COVID 19, similar to the insights of Irish teachers (O'Keeffe and McNally 2020).

The first week we talked a lot about the situation and I think I managed to calm the children down. [...] We take the children out after breakfast and they are on the playground, lawn, forest, walking until lunch [...] [Segment of preschool teachers' answers, No 1, Slovenia]

Difficulties with re-social inclusion [...] we overcame with conversations and social games. [Segment of preschool teachers' answers, No 6 , Slovenia]

I think I was efficient because I am adaptable and flexible, and I prepared well [] [Segment of preschool teachers' answers, No 5, BiH] 
We devoted more time to the rules and allowed the children the more free play they wanted. [Segment of preschool teachers' answers, No 8, Slovenia]

At a time when kindergartens were closed, although online education was organized for preschool children in some countries (Dong, Cao, and Li 2020; Gayatri 2020) was absent, there was a tendency to maintain contact with children and parents, which had a positive impact on the inclusion of children in kindergarten when reopening the kindergarten.

We did not have live contact with parents and children for some time, so we communicated via emails and phone calls. Instead of activities that we would implement in kindergarten, I prepared ideas and activities for children that were help for parents to work and play at home [...] [Segment of preschool teachers' answers, No 10, Slovenia]

\section{Cooperation of Parents and Preschool Teachers during the Adaptation of Children to Kindergarten in the Changed Conditions of COVID 19}

Respondents' insights indicate different emotional, social, and behavioural responses of parents in the context of COVID 19 and their children's adaptation to kindergarten. All this indicates that there are completely different attitudes of parents about the pandemic, the degree of responsibility and the subjective experience of danger. What we can see through the analysis of most of the answers is that opening a kindergarten for parents was a relief, and for a certain number a certain degree of concern. It is noticed that communication with parents in these conditions requires a higher degree of understanding and empathy on the part of preschool teachers, and that preschool teachers try to calm down and encourage worried parents.

There was increased concern from parents, but also relief from the reopening of the kindergarten. [Segment of preschool teachers' answers, No 6, BiH]

In most examples, I felt that reopening was a great relief for parents [...] Some parents experienced that their children would be denied socialization. [Segment of preschool teachers' answers, No 4, Slovenia]

Some parents inquired about how the day was going in kindergarten and were reassured when we told them that we preferred the health of the children over other goals. [Segment of preschool teachers' answers, No 7, Slovenia] 
In the beginning, there was fear, but it passed quickly because we did it because we were calm and instilled confidence. [Segment of preschool teachers' answers, No 9, BiH]

Based on the analysis of the respondents' answers, it can be concluded that the cooperation with parents, although achieved at a lower level than before due to physical distance measures and prohibition of parents' presence in preschools, was satisfactory in the context of children's adaptation to kindergarten. Parents have the right to be involved in the work of kindergartens, so it is necessary to identify opportunities and implement new forms of cooperation between parents and preschool teachers (Lepičnik Vodopivec 2012), which is certainly important in the process of adaptation of children. The lack of parent meetings, individual consultations, workshops and other forms of cooperation with parents within the institution was attempted to be compensated through electronic and other media. The cooperation mostly moved from the real to the media context.

Relationships with parents have not changed regardless of the introduced measures [...] Parents receive first-hand information at the entrance to the kindergarten, by phone calls, letters [...] we inform them about daily activities through the site and pictures on usb. [Segment of preschool teachers' answers, No 10, $\mathrm{BiH}]$

We received the necessary information when picking up the children, and we conducted other conversations by phone or e-assistant. I think that the communication went smoothly, but still, it cannot be equated with a personal conversation. [Segment of preschool teachers' answers, No 7, Slovenia]

I sent them different things, tasks, photos, powerpoint with stories, recordings of children every week. We heard and saw some of them through various applications (viber, zoom ...). Some were happy to send me photos and recordings. I did it myself. [Segment of preschool teachers' answers, No 5, Slovenia]

\section{Specifics and Success of Children's Adaptation to Kindergarten in the Changed Conditions of COVID 19}

According to the insights and statements of the respondents, the adaptation of newly arrived children to kindergarten was just as successful as before, and in some cases more successful, faster and less painful. Due to the reduced 
number of children in the kindergarten, the kindergarten environment was more accessible and similar to the environment to which the newcomer was already accustomed than before. The adaptation of a child to kindergarten is more successful if the kindergarten and family environment are similar (Kamenov 2006). Also, in such conditions, the preschool teachers had more time to dedicate to each child individually and get to know them. Establishing a safe connection between the preschool teachers and the child is a very important component for introducing children to kindergarten (Cugmas 2010). The inability of parents to access the kindergarten and the rapid separation from children at the front door in several cases contributed to faster independence and adaptation of children, while in rare cases it was an aggravating circumstance. Parents talked more with their children at home about kindergarten and thus prepared them, and a quick departure made it impossible for them to express extortionate emotions and patterns of behaviour on the part of the children. Recognizing the reactions of parents to certain emotions, some children, by emphasizing such an emotion, manipulate and extort from their parents what they want (Milivojević 2008) and are a frequent occurrence when children adapt to kindergarten. Concerned parents, who are unable to understand the background of such emotional reactions, unknowingly complicate the process of adaptation for their own child.

The new rules in the kindergarten were not a problem during the adaptation. Getting children used to a higher level of hygiene and triage procedures was not a problem. The more time that children spent outdoors in play, the satisfaction and happiness of children due to the possibility of re-socializing and meeting social needs, and the smaller number of children in the group of preschool teachers can be singled out as factors that positively influenced children's adaptation.

Children who were already in kindergarten had a higher level of happiness when returning to the institution and meeting with friends and preschool teachers, and in rare cases they had to be re-adapted.

Thanks to our dedication and quick separation from parents, the adaptation went easier and faster. Probably parents with children also made good preparation at home through conversation. [Segment of preschool teachers' answers, No 1, BiH]

They have a harder time separating from their parents but they like to measure their temperature and wash their hands. In a short time they became independent. I consider the adaptation perhaps even more successful because there are fewer children, increased hygiene and 
children are healthier because the first symptoms of respiratory infections are isolated and treated at home. [Segment of preschool teachers' answers, $\mathrm{No} 4, \mathrm{BiH}]$

Differences in adaptation today and before COVID are not very noticeable, but significant positive effects in the speed of social inclusion are noticeable, separation fear was less pronounced [...] we turned stricter rules of hygiene, disinfection and temperature measurement into a game [...] [Segment of preschool teachers' answers, No 8, BiH]

There were no special negative changes in the children when they returned to kindergarten, they were very happy to see each other again and play together. They wanted to play together - primarily older children. [Segment of preschool teachers' answers, No 7, Slovenia]

It is possible during adaptation to make it easier for parents, because before they miss the child, they have less problems handing over the child and entrusting the child, because they have a shorter takeover time and the parent is left to the current regime. [Segment of preschool teachers' answers, No 4, Slovenia]

\section{Specifics of Adaptation of Children to Kindergarten in the Changed Conditions of COVID 19 in the Republic of Srpska and the Republic of Slovenia}

In the Republics of Slovenia and Bosnia and Herzegovina, certain time differences were observed in the context of the presence of COVID 19 and related measures to prevent the spread of this contagious disease, which resulted in the periods of operation and closure of kindergartens not completely coinciding in both countries. However, the thematic analysis of the respondents' responses and the overall analysis process for all participants in the process of adaptation of children to kindergarten (children, preschool teachers and parents) did not show differences in the process and success of adaptation of children to kindergarten during the pandemic between the two countries.

\section{Conclusion}

Through a comparative case study, we looked at and tried to understand the adaptation of children to kindergarten (children who went to kindergarten for the first time, but also children who started kindergarten again after a long break) in changed conditions during the COVID 19 pandemic for all participants involved in the process (children, preschool teachers and parents) based on the insights of twenty preschool teachers from Slovenia and 
Bosnia and Herzegovina. Based on the analysis of the responses, it was noticed that the adaptation was successful, and in some cases more successful than usual. Considering Brofenbrenner's theory (1981) of ecosystems important for children, good functionality of microsystems (kindergarten and family) and mesosystems (cooperation of parents and preschool teachers) can be seen as important factors in the development of children's resilience during the COVID 19 pandemic and their adaptation to kindergarten. Good organization of kindergartens, successful teamwork of employees, new strategies of educational work in the context of recommendations for pandemic protection measures, and social support for children are just some of the factors that have contributed to the efficiency of adaptation. Our research indicates a high level of autonomy of pedagogical workers in both countries. Emphasized emotional stability, empathy, flexibility, readiness for change and new forms of cooperation with parents were noticed in preschool teachers, which are also important factors that contributed to the success of adaptation. Parents also showed a high level of understanding and willingness to cooperate with preschool teachers in the changed conditions. We did not notice any differences between the insights of preschool teachers from the Republics of Slovenia and Bosnia and Herzegovina in the context of the success of children's adaptation to kindergarten in the changed conditions of COVID 19.

\section{References}

Bronfenbrenner, U. 1981. The Ecology of Human Development: Experiments by Nature and Design. Cambridge, MA and London: Harvard University Press.

Cugmas, Z. 2010. 'Uporaba teorije navezanosti v vrtcih.' Pedagoška obzorja 25 (1): $3-18$.

Čikić, J., and A. Bilinović Rajačić. 2020. 'Family Practices during the Pandemic and the State of Emergency: The Female Perspective.' Sociological Review 3:799-836.

Dong, C., S. Cao, and H. Li. 2020. 'Young Children's Online Learning during COVID-19 Pandemic: Chinese Parents' Beliefs and Attitudes.' Children and Youth Services Review 118:105440. https://doi.org/10.1016/j.childyouth.2020 .105440 .

Flottman, R., A. McKernan, and C. Tayler. 2011. 'Victorian Early Years Learning and Development Framework: Evidence Paper; Practice Principal 2: Partnerships with Professionals.' The University of Melbourne, Melbourne Graduate School of Education. https://www.education.vic.gov.au/ Documents/childhood/providers/edcare/pracpartner.pdf.

Gayatri, M. 2020. 'The Implementation of Early Childhood Education in the Time of Covid-19 Pandemic: A Systematic Review.' Humanities \& Social Sciences Reviews 8 (6): 46-54. 
Iftene, C. 2014. 'Educational Sistems Autonomy: Facts and Analysis.' Procedia: Social and Behavioral Sciences 142:47-53.

Jokić Begić, N., I. Hromatko, T. Jurin, Ž. Kamenov, G. Keresteš, G. Kuterovac Jagodić, A. Lauri Koralija, D. Maslić Seršić, J. Mehulić, U. Mikac, M. Tadinac, J. Tomas, and C. Sangster Jokić. 2020. Kako smo? Život u Hrvatskoj u doba korone. Zagreb: Filozofski fakultet.

Kamenov, E. 2006. Dečja igra: vaspitanje i obrazovanje kroz igru. Beograd: Zavod za udžbenike.

Kroflič, R. 2001. 'Temeljne predpostavke, načela in cilji kurikula za vrtce.' In Otrok $v$ vrtcu, edited by L. Marjanovič Umek, 7-26. Maribor: Obzorja.

Kruger, A., and I. Reddemann. 2013. Psihodramska imaginativna terapija traume za djecu i mlade. Goražde: Udruženje žena SEKA.

Kuckartz, U. 2014. Qualitative Text Analysis. London: Sage.

Lepičnik Vodopivec, J. 2012. Teorija in praksa sodelovanja s starši. Ljubljana: Pedagoška fakulteta.

Merriam, S. B., and J. Tisdell. 2015. Qualitative Research: A Guide to Design and Implementation. San Francisco, CA: Jossey-Bass.

Milivojević, Z. 2008. Emocije - razumevanje čustev $v$ psihoterapiji. Translated by I. M. Ravnik and S. Ravnik. Novi Sad: Psihopolis institut.

Morse, J. M., M. Barrett, M. Mayan, K. Olson, and J. Spiers. 2002. 'Verification Strategies for Establishing Reliability and Validity in Qualitative Research.' International Journal of Qualitative Methods 1 (2): 13-22.

Nacionalni inštitut za javno zdravje. 2020. 'Higienska preporočila za vrtce v času epidemije COVID.' https://www.nijz.si/sites/www.nijz.si/files/uploaded/ vrtci_s_prilogami.pdf.

O'Keeffe, C., and S. McNally. 2021. 'Uncharted Territory: Teachers' Perspectives on Play in Early Childhood in Classrooms in Ireland during the Pandemic.' European Early Childhood Education Research Journal 29 (1): 79-95.

Plevnik, T., ed. 2008. Ravni avtonomije in odgovornosti učiteljev v Evropi: Eurydice informacijsko omrežje o izobraževanju v Evropi. Ljubljana: Ministrstvo za šolstvo in šport.

Profaca, B., and L. Arambašić. 2009. 'Traumatski događaj i trauma kod djece i mladih.' Klinička psihologija 2 (1-2): 53-74.

Shah, M. 2012. 'The Importance and Benefits of Teacher Collegiality in Schools: A Literature Review.' Procedia: Social and Behavioral Sciences 46:1242-1246.

Spinelli, M., F. Lionetti, M. Pastore, and M. Fasolo. 2020. 'Parents' Stress and Children's Psychological Problems in Families Facing the COVID-19 Outbreak in Italy.' Frontiers in Physiology 3 (11): 1713. https://doi.org/10.3389/fpsyg.2020 .01713.

Stoiljković, C. 2020. 'The Impact of the Covid-19 Pandemic on the Educational Work of Kindergarten Teachers.' International Journal of Cognitive Research in Science, Engineering and Education 8 (3): 123-133. 
Velan, D., and S. Tatalović Vorkapić. 2020. 'Contextual Determinants of Kindergarden Culture as Indicators of Children's Well-Being during Their Transition and Adaptation.' Ekonomska istraživanja 33 (1): 1182-1193.

Vilig, K. 2016. Kvalitativna istraživanja u psihologiji. Beograd: Clio.

Zakon o predškolskom vaspitanju i obrazovanju Republike Srpske. 2020. Službeni glasnik Republike Srpske, no. 63.

Zupančič, J. 2013. 'Razmislek o razsežnostih avtonomije ravnateljev v slovenski osnovni šoli.' Vodenje v vzgoji in izobraževanju 11 (1): 117-131.

\section{Prilagajanje otrok na vrtec v spremenjenih pogojih zaradi covida-19}

Pandemija covida-19 je vplivala na spremembne tudi na področju vzgoje in izobraževanja. Spremembe zaznamo tudi v kontekstu prehoda otrok iz enega v drugo okolje, torej na prehodu iz družinskega v vrtčevsko okolje. Cilj naše kvalitativne raziskave je preučiti izkušnje vseh deležnikov vzgoje in izobraževanja v vrtcih (otrok, vzgojiteljic in staršev) v Republiki Sloveniji ter Bosni in Hercegovini v času med pandemijo. S študijo primera smo s pomočjo vpogleda vzgojiteljic ugotavljali prilagajanje otrok na vrtec v spremenjenih pogojih pandemije covida-19. V ta namen smo oblikovali instrument s šestimi vprašanji odprtega tipa, s katerim smo anketirali 20 vzgojiteljic (iz vsake države po deset). Podatki, pridobljeni v marcu 2021, osvetljujejo posebnosti prilagajanja otrok na vrtec v času pandemije ter izkušnje otrok, vzgojiteljic in staršev z vidika anketiranih vzgojiteljic. Na podlagi dobljenih podatkov ugotavljamo, da je bilo po mnenju anketiranih prilagajanje uspešno in v nekaterih primerih celo uspešnejše kot običajno.

Ključne besede: prilagajanje otrok vrtcu, profesionalne izkušnje vzgojiteljic, sodelovanje vzgojiteljic s starši 